\title{
Wrestling with objectivity and fairness: U.S. environment reporters and the business community
}

\author{
David B. Sachsman \\ James L. Simon \\ Fairfield University, jsimon@fairfield.edu \\ JoAnn Meyer Valenti
}

Follow this and additional works at: https://digitalcommons.fairfield.edu/english-facultypubs Copyright 2005 Taylor and Francis

This is an Author's Original Manuscript of an article whose final and definitive form, the Version of Record, has been published in Applied Environmental Education and Communication: An International Journal, 4(4), 363-373. [copyright Taylor \& Francis], available online at: http://www.tandfonline.com/10.1080/15330150500302239

\section{Repository Citation}

Sachsman, David B.; Simon, James L.; and Valenti, JoAnn Meyer, "Wrestling with objectivity and fairness: U.S. environment reporters and the business community" (2005). English Faculty Publications. 61. https://digitalcommons.fairfield.edu/english-facultypubs/61

\section{Published Citation}

Sachsman, David B.; Simon, James \& Valenti, JoAnn Myer (2005). "Wrestling with objectivity and fairness: U.S. environment reporters and the business community." Applied Environmental Education and Communication: An International Journal, 4(4), 363-373.

This item has been accepted for inclusion in DigitalCommons@Fairfield by an authorized administrator of DigitalCommons@Fairfield. It is brought to you by DigitalCommons@Fairfield with permission from the rightsholder(s) and is protected by copyright and/or related rights. You are free to use this item in any way that is permitted by the copyright and related rights legislation that applies to your use. For other uses, you need to obtain permission from the rights-holder(s) directly, unless additional rights are indicated by a Creative Commons license in the record and/or on the work itself. For more information, please contact digitalcommons@fairfield.edu. 


\title{
WRESTLING WITH OBJECTIVITY AND FAIRNESS
}

\author{
U.S. Environment Reporters and the Business Community
}

David B. Sachsman

West Chair of Excellence in Communication and Public Affairs

210 Frist Hall, Dept. 3003

University of Tennessee at Chattanooga

$615 \mathrm{McCallie}$ Ave.

Chattanooga, TN 37403

David-Sachsman@utc.edu

(423) 425-4219, fax (423) 425-2199

\author{
James Simon \\ Department of English \\ Fairfield University \\ Fairfield, CT 06430 \\ jsimon@mail.fairfield.edu
}

(203) 254-4000 ext. 2792, fax (203) 254-4131

JoAnn Myer Valenti

Independent Scholar

valentij@byu.edu

(801) 942-8516

Authors' Note: The authors' names are listed in alphabetical order; each contributed equally to the study. Address correspondence to David Sachsman, West Chair of Excellence in Communication and Public Affairs, 210 Frist Hall, Dept. 3003, University of Tennessee at Chattanooga, 615 McCallie Ave., Chattanooga, TN 37403; phone: 423-425-4219; fax: 423-4252199; e-mail: David-Sachsman@utc.edu.

An earlier version of this research was presented at the 3rd Annual Research $\&$ Measurement Conference, International Association of Business Communicators \& Delahaye, New York, N.Y., Sept. 24, 2004.

Copyright $\odot 2004$ by David B. Sachsman, James Simon, and JoAnn Myer Valenti. Published with permission. 


\section{WRESTLING WITH OBJECTIVITY AND FAIRNESS}

U.S. Environment Reporters and the Business Community

Pro-environment and pro-business interests have long been at odds over such issues as economic development. Perhaps as a result, environment reporters have been criticized for allegedly having an antibusiness bias. Yet no comprehensive examination of reporter attitudes has been available to help evaluate such criticism. This study, based on a series of regional surveys including 364 U.S. environment reporters, found the journalists commonly used a business or economics framework for their stories. The reporters used some business organizations as sources more often than some environmental groups. The reporters acknowledged the need to be fair to both corporations and environmental activists. Business interests and advertisers were not commonly viewed as barriers to reporting. At a time when all news organizations face increased scrutiny as to whether they are fair, a substantial minority of these environment reporters said they struggled with the issue of whether their peers are "too green."

Keywords: environment; reporter; journalist; business; fair; objective; green 
Business leaders and environmental activists have long been at odds over how to best protect the environment while also promoting economic growth. This conflict can be seen in press coverage of a variety of issues, ranging from automobile emission standards to suburban sprawl.

Representatives from business groups and business-related institutions have complained that reporters have taken a pro-environment viewpoint on a number of issues that could affect business, including global warming and the proposed Kyoto treaty (Media Research Center [MRC], 2001); pesticide usage on produce (Free Market Project, MRC, 2000); air pollution standards (Bozell, 1997); the health of the national economy ("How media bias colors the news," 2004), and such issues as overpopulation, species extinction, and air and water pollution (Hayward, 2003). Such claims of anti-business bias are not restricted to environmental reporting. Business leaders have complained for decades that reporters, in general, over emphasize negative news in their business coverage (Barchie, 1982; Goidel and Langley, 1995). However, a 1998 study found an increase in the percentage of both positive and negative news reports about businesses, compared to past years, while neutral reports decreased (Ott, 1998).

The question of the objectivity and fairness of environment reporters spilled into public view in reactions to the November 2004 annual meeting 
of the industry's professional group, the Society of Environmental

Journalists. Journalists are socialized into avoiding public displays of support or opposition when covering a speech, a press conference, or other public event. Here, the journalists - technically off duty at a convention gave a standing ovation to a political speech by environmental attorney Robert F. Kennedy Jr., then a muted response to EPA administrator Mike Leavitt the next morning. In his online Environment Writer column, Bud Ward wrote:

The fact is that environmental journalists have a problem perhaps unique to their calling: They are battling the perception that many of them have both inside and beyond their newsrooms of being "greens with press passes," as a former Scripps Howard reporter used to say....The fact is that the SEJ annual meeting is the single most visible manifestation of the field. The shocking/frustrating/ disappointing/disgusting public displays of affection (PDAs) are far more visible than the very worthwhile internal soul-searching those standing Os are triggering among the group's serious and committed members. (November, 2004)

Ward, the former editor of Environment Reporter, argues that journalists in the field need to work harder at battling the public perception that they are advocates:

Those journalists longing to be...perceived as being more committed to the ' $\mathrm{j}$ ' than to the ' $\mathrm{e}$ ' in the term environmental journalism have their work cut out for them. The remedy lies in the most determined, most independent, and most responsible journalism on issues involving natural resources and the environment. It's not an easy road in today's media climate. It's just the only one that has even the faintest chance of working in the long run. (Ward, November 2001) 
Bob Lutgen, the managing editor for operations at the Chattanooga Times Free Press, says that environmental writers might start out unbiased, but that the environmental groups' public relations are just so good that stories may not appear to be objective (personal communication, December 12, 2004). On the other hand, business owners are very timid about talking to environment reporters, according to Lutgen the former managing editor of the Arkansas Democrat Gazette: "In Little Rock, we had an environmental writer doing a story on chicken plants, but could not get a comment from Tyson. We didn't see how we could run environmental stories without comments from business."

*In the long run the Arkansas Democrat Gazette dropped the environment beat. "We dropped the beat, but we didn't drop the coverage," said Lutgen. "The issue is very important and [generates] high readership, but it is easier to spread it around so that individual reporters don't get so close to the stories' sources that they become biased."

(move next two grafs up from lit review) Business-related critics have faulted environment reporters for offering a "pervasive pessimism about the future that has become the hallmark of today's environmental orthodoxy" (Hayward, 2003, p. 36). Environment reporters are seen as endowing moral authority on environmental advocacy organizations while at the same time viewing industry, with its focus on profit motives, more skeptically. Steven F. Hayward, a fellow of the American Enterprise Institute, argues, "This 
tends to lead to asymmetry in news coverage, with the claims of environmental advocates accepted at face value, while industry claims are often overlain with, for instance, the amount of campaign contributions an industry has given to political office holders (as if environmental groups don't put money into politics)" (2003, p. 36).

Yet others feel that reporters can grow impatient with the "purist approach and quasi-religious zeal" of environmental activists (Dennis, 1991, p. 62).

The news media are the major source, for the public, about such issues as science, risk, and hazards (Hornig, 1990; Singer and Endreny, 1987; Slovic, 1987). Environment beat reporters serve as a link between environmentalists, business leaders, and the general public. They serve in an agenda-setting role, alerting the public as to what to think about (Carroll and McCombs, 2003) and supplying people with most of their information about corporations (Coombs, 2004). Corporate crises can develop following negative environmental reporting about a company, such as contamination of Perrier bottled water or corn gene-splicing leading to taco shell contamination at Taco Bell, especially if product harm results in death (Dean, 2004). But efforts to study environmental journalists have been hampered by the lack of a comprehensive survey of such reporters at daily newspapers and television news stations. 
The lack of data about environment reporters may be due in part to the relative newness of this specialized area of reporting, which surfaced widely in the late 1960s, the 1970s, and the 1980s (Carmody, 1995; Friedman, 2003). The number of journalists at work in this area is now substantial; one professional organization, the Society of Environmental Journalists, founded in 1990, currently lists some 1,500 members. Environmental reporting "is now firmly entrenched as a key beat in American journalism," writes Paul Rogers in Nieman Reports (p. 32), noting that environmental stories won 10 Pulitzer prizes in the 1990s, compared to a total of nine in the previous three decades.

Claims about a potential tilt in environment coverage are based, in part, on subjective analysis of environment stories. Another approach is to examine the attitudes, work habits, and demographic profiles of the reporters themselves.

This study is based on a series of regional research projects (identifying and then interviewing environment reporters at daily newspapers and television stations) designed to establish baseline data on those U.S. journalists who cover environment stories (Sachsman, Simon \& Valenti, 2002; 2004).

This project (using the results from four regions) tests the assumption that these environment reporters stress nature, wilderness, and the outdoors over other potential story frames. This analysis looks 
specifically at how these reporters handle business and economic stories that might be expected to be at odds with a nature-oriented beat. How often do they use a business angle to frame a story? In choosing sources, are environmental advocacy groups preferred over business groups? Are business groups and advertisers seen as barriers to reporting on the environment? Do these reporters feel they need to be as fair to corporations as they are to environmental activist groups? Do they feel their peers are too pro-environment in their reporting? Is there any evidence that environment reporting is too pro-business? This study answers such questions by using a census, not sample, of environment reporters working at daily newspapers and television stations in 28 states, across four regions of the United States.

\section{RESEARCH QUESTIONS}

As part of a comprehensive survey of environment reporters' processes and attitudes, this project asked questions about the journalist/business community interaction.

1. Do environment reporters commonly use a business angle or framework, compared to other angles?

To examine the use of story frames in environment reporting, the study listed nine potential story angles or frames: government, 
nature/wilderness, human interest, business/economic, politics, pollution, science/technology, health, and risk assessment. Reporters were given a five-point scale and asked to rate each angle as to how often they used it: always, often, sometimes, rarely, or never.

2. How often do environment reporters use business-oriented sources, compared to other sources?

Respondents were asked about 29 different sources (eight federal government offices, seven state-level offices and individuals, four local offices, six environmental groups or individuals, three business-related groups or individuals, and academic researchers). The same five-point scale was used to evaluate how often they used six environmental; and three business sources.

3. Do environment reporters view advertisers or business interests as barriers to environment reporting?

Respondents were presented with 17 potential barriers to their reporting and asked to rate each in terms of it being always a barrier, often, sometimes, rarely, or never.

4. Do environment reporters feel they should be as fair to business sources as they are to sources like environmental advocacy groups?

The reporters were asked to respond to the statement: "Environmental journalists need to be fair to sources such as corporations." They were asked whether they strongly agreed, agreed, disagreed, or strongly 
disagreed. They were also asked about the same question in regards to environmental activist groups.

5. Do environment reporters see their peers as being too brown (probusiness) or too green (pro-environment)?

The reporters were also asked to react to two parallel questions: 1 ) “Environmental journalists tend to be too 'brown' - meaning slanted in favor of business and industry"; and 2): "Environmental journalists tend to be too "green" - meaning slanted in favor of environmentalism." Again, they were asked whether they strongly agreed, agreed, disagreed, or strongly disagreed.

\section{METHOD}

This study used a census approach to identify, contact, and interview environment reporters at U.S. daily newspapers and television stations. Since there is no master list of such reporters, the study relied on an overlapping, multistep process to identify the reporters. Names of potential respondents were gathered from several sources, including the membership lists of the Society of Environmental Journalism and the National Association of Science Writers, the media lists of state and federal environmental agencies, and commercial databases of reporters at various

news organizations. A master list of daily newspapers and TV stations was created from the corresponding year of the Editor and Publisher 
International Yearbook for newspapers and Broadcasting and Cable Yearbook for TV stations.

If a respondent had been identified for a given news organization, that person was called. Respondents were asked if anyone else on the newspaper fit the criteria; they also were asked for the names of anyone at nearby news organizations who might fit the criteria, especially if such reporters routinely attended news conferences about environment issues. If no one had been identified as an environment reporter, a newsroom executive (usually the managing editor for newspapers, assignment editor for TV) was contacted. That person was asked a parallel question: "Do you have anyone who covers the environment on a regular basis as part of their reporting duties?"

The screening question was designed to cast a wide net for reporters who covered the environment as a full-time beat or regularly covered the environment as part of their reporting load. Reporters who had just begun such duties at the time of the survey were included; veteran environment reporters who had been reassigned to other duties at the time of the survey were not included. Interviewers used a 20-page script and conducted a telephone survey that lasted between 22 and 45 minutes. The interviewers included co-authors, trained graduate and honors undergraduate students.

The four regions included 28 of the 50 states. Results are presented separately for each region. Examining results across regions provides a 
sense of whether attitudes or opinions under examination are local to a single region or prevalent across the areas studied.

In New England (in 2000), 55 environment reporters were identified and all 55 were interviewed (100\% response rate). In the Mountain West (in 2001), 91 of 91 reporters were interviewed in (100\% response rate). In the Pacific Northwest (in 2002), 57 of 60 reporters were interviewed (95\% response rate). In the South (in 2002-2003), 151 of 158 reporters were interviewed (95.6\% response rate).

Overall, 46.5 percent of the 550 newspapers contacted had at least one environment reporter. For TV stations, 9.8 percent of the 346 stations surveyed had at least one environment reporter. This study is based on responses from the 364 reporters (315 from newspapers, 49 from television).

\section{FINDINGS}

While this article focuses on how these reporters relate to the business community, two identified job characteristics are worth noting. First, there are few full-time environment reporters working at the newspapers and TV stations surveyed. Instead, most of these reporters cover the environment when a specific story breaks or when they have time away from their other duties. In New England, reporters who covered the environment on a regular basis spent an average (mean) of 37.9 percent of their time on such stories in the preceding year; the bulk of their time was 
spent on other types of stories. In the Mountain West, the average environment reporter spent 50 percent of his or her time on such stories; in the Pacific Northwest, 53.7 percent; and in the South, 44.2 percent.

The part-time nature of the environment beat also was reflected in their job titles. In New England, 18.2 percent of environment reporters had the word "environment" as part of their official job title (e.g., environment reporter, environment writer). Far more common was the title of reporter, general assignment reporter, or staff writer (54.5 percent). The remaining reporters held such titles as science writer, health writer, or specialized reporter. The same tendency held in the other regions.

A business/economics angle or framework was commonly used by journalists in their environment reporting (Table 1). In New England, 91 percent of reporters said they used such an angle either always, often, or sometimes; the percentage was even higher in the other three regions. In at least two regions, the percentage of environment reporters saying they used the business/economics angle was higher than the percentage citing a science/technology angle, a politics angle, a health angle, or a risk assessment angle.

TABLE 1. Combined Percentage of Environment Reporters Saying They Used a Given Story Angle or Frame "Always," "Often" or "Sometimes," By Region 


\begin{tabular}{|c|c|c|c|c|c|c|c|}
\hline $\begin{array}{l}\text { 1. (tie) Gov't; } \\
\text { Pollution; } \\
\text { Human Int. } \\
\text { 4. (tie) Health; } \\
\text { Nature/ } \\
\text { wilderness } \\
\text { 6. Business/ } \\
\text { economics } \\
\text { 7. Science/ } \\
\text { technology } \\
\text { 8. Politics } \\
\text { 9. Risk } \\
\text { assessment }\end{array}$ & $\begin{array}{l}\mathbf{9 1 \%} \\
89 \% \\
84 \% \\
72 \%\end{array}$ & \begin{tabular}{|l} 
1. Gov't \\
2. (tie) Nature/ \\
wilderness; \\
Human Int. \\
4. Business/ \\
economics \\
5. (tie) Politics \\
Pollution \\
7. Science/ \\
technology \\
8. Health \\
9. Risk \\
assessment
\end{tabular} & $\begin{array}{l}\mathbf{9 7 \%} \\
\mathbf{9 0 \%} \\
\mathbf{8 9 \%} \\
78 \% \\
70 \%\end{array}$ & \begin{tabular}{|l} 
1. Gov't \\
2. Human Int. \\
3. Nature/ \\
wilderness \\
4. Pollution \\
5. (tie) \\
Business/ \\
economics \\
Politics \\
7. Science/ \\
technology \\
8. Health \\
9. Risk \\
assessment
\end{tabular} & $\begin{array}{r}100 \% \\
98 \% \\
97 \% \\
\\
95 \% \\
\mathbf{9 3 \%} \\
\end{array}$ & $\begin{array}{l}\text { 1. (tie) Gov't; } \\
\text { Pollution } \\
\text { 3. Human Int. } \\
\text { 4. Business/ } \\
\text { economics } \\
\text { 5. Nature } \\
\text { 6. Science/ } \\
\text { technology } \\
\text { 7. Health } \\
\text { 8. Politics } \\
\text { 9. Risk } \\
\text { assessment }\end{array}$ & $\begin{array}{l}97 \% \\
\\
95 \% \\
\mathbf{9 4 \%} \\
\\
89 \% \\
87 \% \\
\\
86 \% \\
81 \% \\
71 \%\end{array}$ \\
\hline
\end{tabular}

The reporters were asked to rate how often they used 29 types of sources (Table 2). Each source was rated on a five-point scale ranging from always to never; the mean scores for each were then ranked from the highest (a ranking of 1 ) to the lowest (29).

The study found widespread usage of both environment and business sources. Two sources topped the lists in all four regions - generic "local environmental groups" and "individual, local citizens active on the environment." But business sources such as "local manufacturers, developers and other business leaders" were among the sources used most frequently in most regions. The Chamber of Commerce as a source fell in the middle in most regions, along with individual environmental groups. The Chemical Manufacturers Association was ranked near the bottom of all lists, yet cited as being used more frequently than the environmental advocacy group Greenpeace. Environment reporters in this study appeared 
almost as likely to use sources from a business-oriented view point as they

were to use environmental advocacy sources.

TABLE 2. Use of Business Sources vs. Environmental Activists, By Region Combined Percentage of Environment Reporters Saying They Used a Given Source "Always," "Often" or "Sometimes":

\begin{tabular}{|c|c|c|c|}
\hline $\begin{array}{l}\text { New England } \\
\text { (2000) }\end{array}$ & $\begin{array}{l}\text { Mountain West } \\
\text { (2001) }\end{array}$ & $\begin{array}{c}\text { Pacific Northwest } \\
\text { (2002) }\end{array}$ & $\begin{array}{c}\text { South } \\
\text { (2002-03) }\end{array}$ \\
\hline $\begin{array}{ll}\text { 1. } \begin{array}{l}\text { (tie) Local } \\
\text { environment }\end{array} & \\
\text { groups } & \\
\text { 1. } \begin{array}{l}\text { Individual, } \\
\text { local citizens }\end{array} & 100 \% \\
\text { active on the } & \\
\text { environment } & \\
\text { 13. Local } & \mathbf{7 3 \%} \\
\text { manufact., } & \\
\text { developers } & \\
\text { or other } & \\
\text { business } & \\
\text { leaders } & \\
\text { 15. Audubon } & 71 \% \\
\text { Society } & \\
\text { 18. Chambers } & \mathbf{5 5 \%} \\
\text { of Commerce } \\
\text { 19. Sierra Club } & 55 \% \\
\text { 21. NRDC } & 40 \% \\
\text { 28. Chemical } & \mathbf{2 0} \% \\
\text { Manufact. } & \\
\text { Association } & \\
\text { 29. Greenpeace } & 11 \%\end{array}$ & 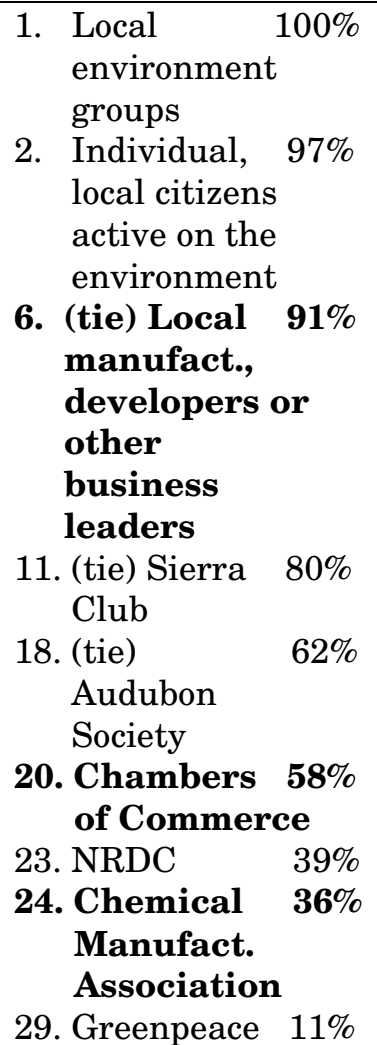 & 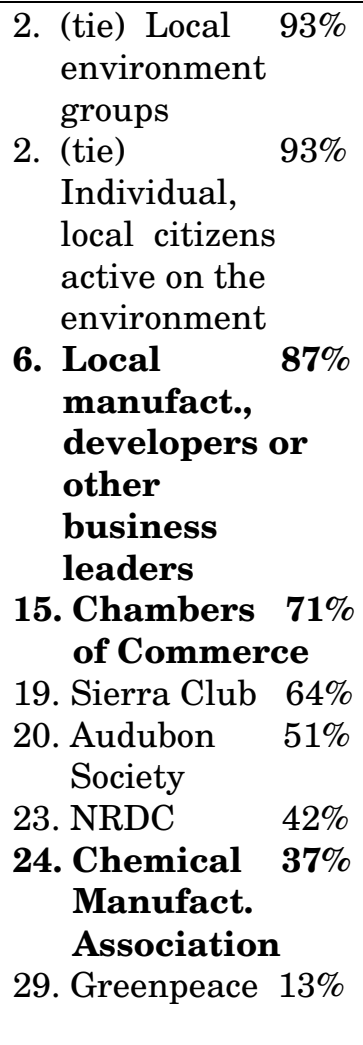 & 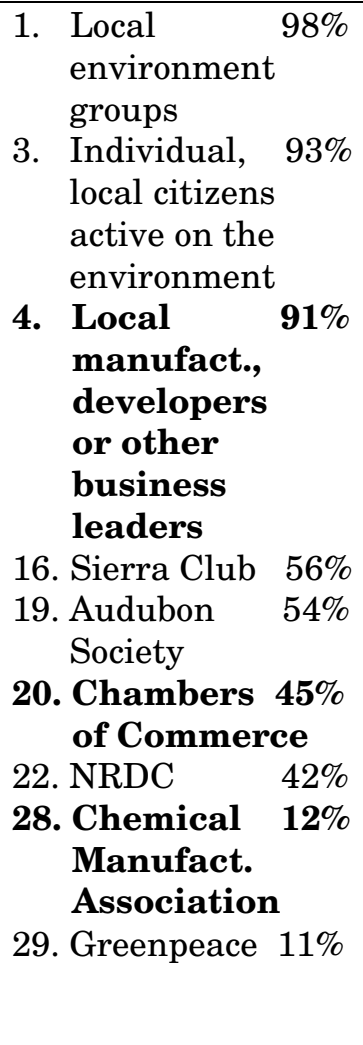 \\
\hline
\end{tabular}

The study also examined whether reporters were likely to cite business groups as a barrier to their environment stories (Table 3). Seventeen potential barriers were presented to reporters; they were asked to rate each on a one to five scale ranging from being always a barrier to never. The results for "always" and "often" were combined into a single percentage and the barriers were rank ordered from high to low. 
The two business-oriented variables - advertisers and other business

interests - were not listed among the top barriers in any of the four regions.

No more than 5.5 percent of reporters cited either business variable as

being a barrier to their reporting. The more common barriers cited were

time constraints, financial constraints, and the size of the news hole.

TABLE 3. Barriers to Reporting, Business Interests vs. Other Factors, by Region Combined Percentage of Environment Reporters Saying Factor was "always" or "often" a barrier:

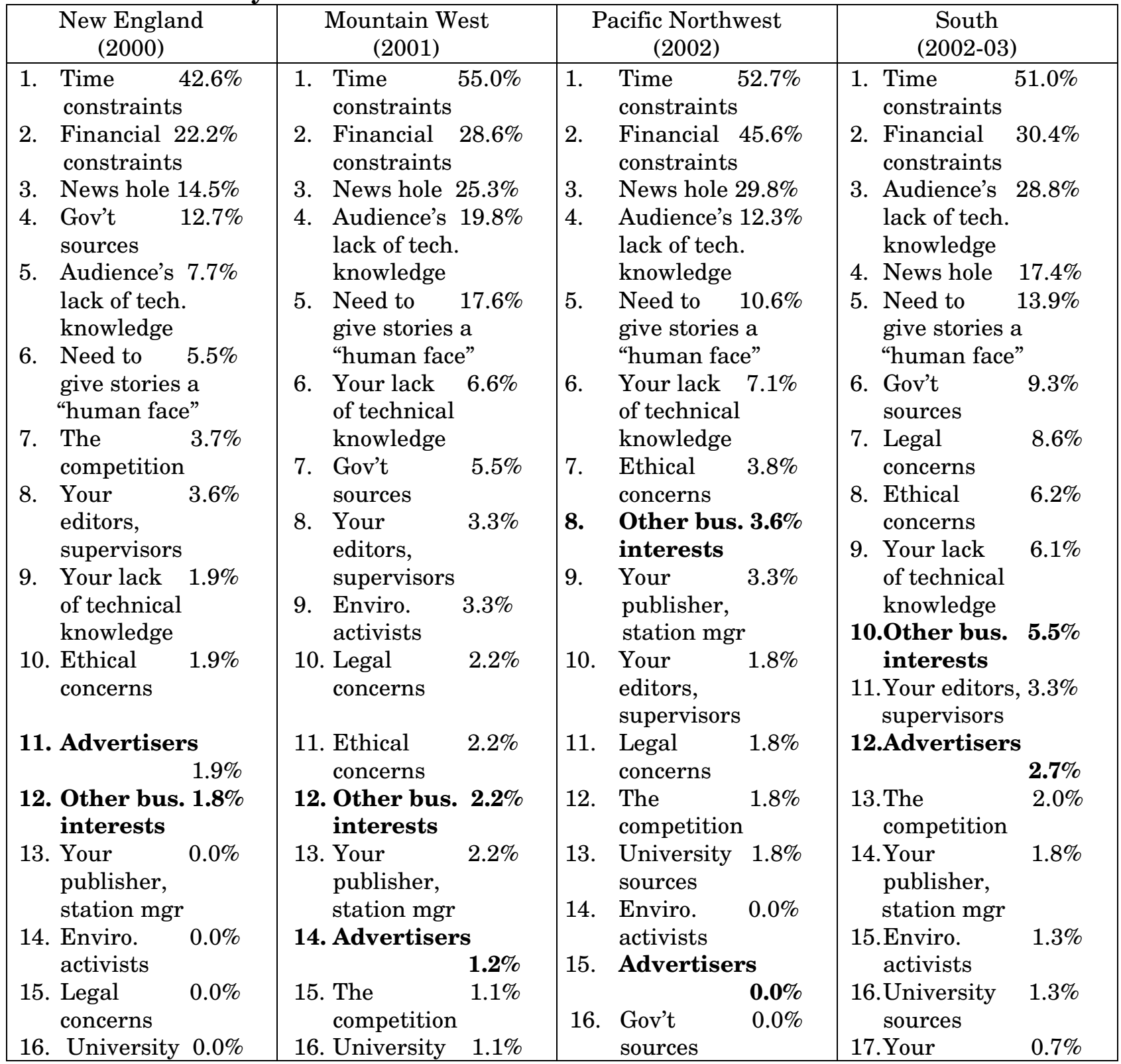




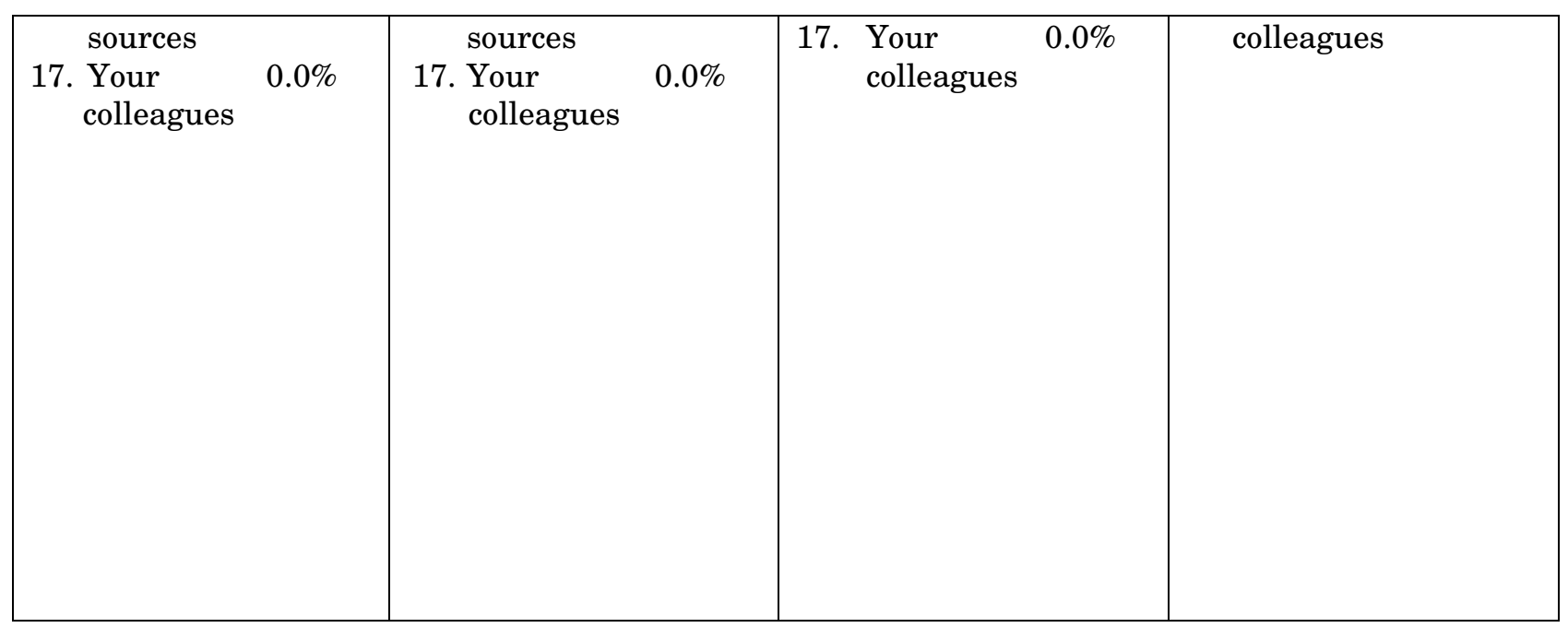

As might be expected, these reporters were consistent in their views regarding the need to be fair to specific sources (Table 4). At least 98 percent of all reporters in all regions agreed or strongly agreed with the statement, "Environmental journalists need to be fair to sources such as corporations." An overwhelming percentage of reporters also agreed with the companion question, "Environmental journalists need to be fair to sources such as environmental activist groups."

TABLE 4. Environment Reporters, on Need to be Fair to Sources such as Corporations and Environment Groups, By Region

Q1 "Environmental journalists need to be fair to sources such as corporations. Do you...

\begin{tabular}{|l|c|c|c|c|}
\hline & $\begin{array}{c}\text { New Eng. } \\
(2000)\end{array}$ & $\begin{array}{c}\text { Mtn. West } \\
(2001)\end{array}$ & $\begin{array}{c}\text { Pacific NW } \\
(2002)\end{array}$ & $\begin{array}{c}\text { South } \\
(2002-03)\end{array}$ \\
\hline $\begin{array}{l}\text { Strongly } \\
\text { Agree }\end{array}$ & $46.3 \%$ & $41.8 \%$ & $52.6 \%$ & $61.7 \%$ \\
\hline Agree & $53.7 \%$ & $58.2 \%$ & $45.6 \%$ & $37.6 \%$ \\
\hline Disagree & $0.0 \%$ & $0.0 \%$ & $1.8 \%$ & $0.7 \%$ \\
\hline $\begin{array}{l}\text { Strongly } \\
\text { Disagree }\end{array}$ & $0.0 \%$ & $0.0 \%$ & $0.0 \%$ & $0.0 \%$ \\
\hline
\end{tabular}




\begin{tabular}{|l|c|c|c|c|}
\hline TOTAL & $100 \%$ & $100 \%$ & $100 \%$ & $100 \%$ \\
\hline$N$ & 54 & 91 & 57 & 149 \\
\hline
\end{tabular}

Q2 "Environmental journalists need to be fair to sources such as environmental activist groups. Do you...

\begin{tabular}{|l|c|c|c|c|}
\hline & $\begin{array}{c}\text { New Eng. } \\
(2000)\end{array}$ & $\begin{array}{c}\text { Mtn. West } \\
(2001)\end{array}$ & $\begin{array}{c}\text { Pacific NW } \\
(2002)\end{array}$ & $\begin{array}{c}\text { South } \\
(2002-03)\end{array}$ \\
\hline $\begin{array}{l}\text { Strongly } \\
\text { Agree }\end{array}$ & $46.3 \%$ & $36.3 \%$ & $56.1 \%$ & $58.0 \%$ \\
\hline Agree & $53.7 \%$ & $63.7 \%$ & $42.1 \%$ & $41.3 \%$ \\
\hline Disagree & $0.0 \%$ & $0.0 \%$ & $1.8 \%$ & $0.7 \%$ \\
\hline $\begin{array}{l}\text { Strongly } \\
\text { Disagree }\end{array}$ & $0.0 \%$ & $0.0 \%$ & $0.0 \%$ & $0.0 \%$ \\
\hline TOTAL & $100 \%$ & $100 \%$ & $100 \%$ & $100 \%$ \\
\hline$N$ & 54 & 91 & 57 & 150 \\
\hline
\end{tabular}

When the reporters were asked about whether their peers were slanted in their reporting, their responses were less favorable (Table 5). While most reporters, ranging from 91.3 percent in the Pacific Northwest to 97.5 percent in the Mountain West, rejected the statement, "Environmental journalists tend to be too 'brown', meaning slanted in favor of business and industry," they were far more divided on the question of whether "Environmental journalists tend to be too "green," meaning slanted in favor of environmentalism. In all four regions a majority of reporters said they disagreed or strongly disagreed. However, a sizable minority, ranging from 38 percent in the Mountain West to 46.5 percent in New England, agreed 
with the statement. While reporters themselves feel that it is important to be fair to sources such as corporations (Table 4), a substantial minority feel that their peers tend to be too "green" (Table 5).

TABLE 5. Environment Reporters, on Potential Slant in Reporting of Peers, By Region

Q1: "Environmental journalists tend to be too "brown" - meaning slanted in favor of business and industry. Do you..."

\begin{tabular}{|l|c|c|c|c|}
\hline & $\begin{array}{c}\text { New Eng. } \\
\text { (2000) }\end{array}$ & $\begin{array}{c}\text { Mtn. West } \\
\text { (2001) }\end{array}$ & $\begin{array}{c}\text { Pacific NW } \\
\text { (2002) }\end{array}$ & $\begin{array}{c}\text { South } \\
\text { (2002-03) }\end{array}$ \\
\hline $\begin{array}{l}\text { Strongly } \\
\text { Agree }\end{array}$ & $2.0 \%$ & $2.5 \%$ & $8.7 \%$ & $5.2 \%$ \\
\hline Agree & $2.0 \%$ & $0.0 \%$ & $0.0 \%$ & $0.0 \%$ \\
\hline $\begin{array}{l}\text { Disagree } \\
\text { Strongly } \\
\text { Disagree }\end{array}$ & $87.8 \%$ & $88.8 \%$ & $87.0 \%$ & $85.1 \%$ \\
\hline $\begin{array}{l}\text { TOTAL } \\
* \text { does not }= \\
\text { 100\% due to } \\
\text { rounding }\end{array}$ & $100 \%$ & $100.1 \% *$ & $100 \%$ & $100 \%$ \\
\hline N & 49 & $8.8 \%$ & $4.3 \%$ & \\
\hline
\end{tabular}

Q2: "Environmental journalists tend to be too "green" - meaning slanted in favor of environmentalism. Do you...”

\begin{tabular}{|l|c|c|c|c|}
\hline & $\begin{array}{c}\text { New Eng. } \\
\text { (2000) }\end{array}$ & $\begin{array}{c}\text { Mtn. West } \\
\text { (2001) }\end{array}$ & $\begin{array}{c}\text { Pacific NW } \\
\text { (2002) }\end{array}$ & $\begin{array}{c}\text { South } \\
\text { (2002-03) }\end{array}$ \\
\hline $\begin{array}{l}\text { Strongly } \\
\text { Agree }\end{array}$ & $0.0 \%$ & $1.4 \%$ & $0.0 \%$ & $0.8 \%$ \\
\hline Agree & $46.5 \%$ & $36.6 \%$ & $44.7 \%$ & $41.4 \%$ \\
\hline $\begin{array}{l}\text { Disagree } \\
\begin{array}{l}\text { Strongly } \\
\text { Disagree }\end{array}\end{array}$ & $53.5 \%$ & $57.7 \%$ & $53.2 \%$ & $54.1 \%$ \\
\hline $\begin{array}{l}\text { TOTAL } \\
\text { *does not } \\
\text { 100\% due to } \\
\text { rounding }\end{array}$ & $100 \%$ & $99.9 \% *$ & $100 \%$ & $100.1 \% *$ \\
\hline
\end{tabular}




\begin{tabular}{|l|l|l|l|l|}
\hline$N$ & 43 & 71 & 47 & 133 \\
\hline
\end{tabular}

\section{SUMMARY}

This study surveyed environmental journalists in 28 states in four regions of the country about their attitudes toward business sources and the framing of the stories they cover. The standard limitations of survey research apply, and these findings do not analyze the quality or quantity of published or aired environment stories. The data reported in this study are intended to provide a baseline for future research and establish systematically collected responses from an identified, whole population of specialty beat journalists.

Most importantly, the environment reporters surveyed do not, in their reported work habits, evidence the anti-business bias claimed by critics. These reporters commonly use a business/economics framework for their stories. Local business-oriented sources (local manufacturers, Chamber of Commerce) are routinely used. Advertisers or other business interests were not seen as barriers to their reporting. Results found overwhelming support among environment reporters, at least 98 percent in each region, for the need to be fair to both business and environmental activist sources.

At least 91 percent of reporters in each region rejected the notion that their peers tend to be too pro-business. And while a majority of 
reporters in all four regions rejected the idea that their peers are too "green" or pro-environmental, a substantial minority - as many as 38 percent of reporters in each region - agreed with the statement that their peers are too green. Thus, many environment reporters appear to be wrestling with this question of objectivity and fairness.

Nevertheless, this study demonstrates that environmental journalists recognize the importance of the business community. Their stories include a business angle and routine use of business sources. The reporter bias most clearly evident in these findings is a preference for local sources, be they government representatives, local citizens, or members of the local business community. Still, a substantial minority of these environment reporters think their colleagues "tend to be too green." Whether or not significant numbers of environment reporters are truly biased, the perception of reporter bias clearly exists inside the newsroom as well as among industry leaders.

\section{REFERENCES}

Barchie, L. (1982). Business and the media. Freedom of Information Center FOI-463. Columbia, MO.

Bozell, L. B. III (1997, July 10). Flat earth environmental reporting. Syndicated Column, Creators Syndicate. Retrieved December 20, 2004, from http://www.mediaresearch.org/BozellColumns/ newscolumn/1997/col19970710.asp.

Carmody, J. (1995, May/June). It's a jungle out there: Environmental 
journalism in an age of backlash. Columbia Journalism Review, 4045.

Carroll, C.E. and McCoombs, M. (2003). Agenda-setting effects of business news on the public's image and opinions about major corporations. Corporate Reputation Review, 6, 36-46.

Coombs, W.T. (2004). Impact of past crises on current crisis communication. Journal of Business Communication, 41:3, 265-289.

Dean, D.H. (2004). Consumer reaction to negative publicity. Journal of Business Communication, 41:2, 192-211.

Dennis, E. E. (1991). In context: Environmentalism in the system of news. Media and the Environment. Washington: Freedom Forum Media Studies Center. 55-64.

Environmental knowledge gap, (1995). Science, 268, 647.

Free Market Project, Media Research Center (2000, August 29). Media Aid Environmental Hit Job on ABC Reporter. MediaNomics. 8:1.

Friedman, S. (2003). The third decade of environmental journalism: A qualitative review. Paper presented at Association for Education in Journalism and Mass Communication conference, Kansas City, MO, August 1, 2003

Goidel, R.K. and Langley, R.E. (1995). Media coverage of the economy and aggregate economic evaluations: Uncovering evidence of indirect media effects. Political Research Quarterly, 48:2, 13-28.

Hansen, A. (Ed.) (1993). The mass media and environmental issues. London: Leicester University Press.

Hayward, S. (2003, July/August). Mixed atmosphere: Good and bad environmental reporting swirl together. The American Enterprise, 3638.

Hornig, S. (1990). Science stories: Risk, power and perceived emphasis. Journalism Quarterly, 77:4, 767-776.

How media bias colors the news. (2004, October 25). Investor's Business 
Daily. Lexis-Nexis, Retrieved December 16, 2004, from

http://web.lexisnexis.com/universe/document?_m=499e136769c770d6

b3866a822d7e789f\&_docnum $=1 \& w c h p=d G L b V 1 b-z S k V A$

\&_md5=36ee9fcba09d7bab4533aac925684416.

Kafatos, F.C. and Eisner, T. (2004). Unification in the century of biology. Science, 303, 1257.

Krieghbaum, H. (1940). The background and training of science writers. Journalism Quarterly, 17, 15-18.

LaFollette, M.C. (2004). Pragmatic popularization: Historical perspectives on media presentation of engineering research. Paper presented at the annual meeting of the American Association for the Advancement of Science, Seattle, WA.

Lutgen, Bob. (personal communication, December 12, 2004).

Media Research Center, Free Market Project (2001, May 7). Clamoring for Kyoto: The networks'one-sided coverage of global warming. Retrieved December 20, 2004, from http://secure.mediaresearch. org/specialreports/fmp/2001/globalwarming.html.

Nelkin, D. (1995). Selling science: How the press covers science and technology. New York: Freeman and Company.

Ott, K. (1998, October). Media study finds more bias in news reports on companies. Business Marketing, 83:10, 2.

Pew Research Center for the People and the Press. (2002, 2004). Retrieved December 20, 2004, from http://www.stateofthemedia.org/ journalist_survey.html.

Rogers, P. (2002, winter). Complexity in environment reporting is critical to public decision-making: '.. the craft is now firmly entrenched as a key beat in American journalism.' Nieman Reports 56:4, 32.

Sachsman, D.B. (1973). Public Relations Influence on Environmental Coverage (in the San Francisco Bay Area). Doctoral dissertation, Stanford University.

Sachsman, D.B., Simon, J. and Valenti J.M. (2002). The environment 
reporters of New England. Science Communication. 23:4, 410-41.

Sachsman, D.B., Simon, J. and Valenti J.M. (2004). Risk and the environment reporters: A four-region analysis. Public Understanding of Science, 13, 399-416.

Schwitzer, G. (1992). The magical medical media tour. Journal of the American Medical Association, 267:14, 1969-72.

Singer, E. and Endreny, P. (1987). Reporting hazards: Their benefits and costs. Journal of Communication, 37:3, 19026.

Slovic, P. (1987, April 17). Perceptions of risk. Science, 280-285.

Storad, C.J. (1984). Who are the metropolitan daily newspaper science journalists, and how do they work? Newspaper Research Journal, $6: 1,39-48$.

Suzuki, D. (2003). A look at world parks. Science, 301, 1289.

Tanner, A.H. (2004). Agenda building, source selection, and health news at local television stations. Science Communication. 25:4, 350-63.

Valenti, J.M. (1998). Ethical decision making in environmental communication. Journal of Mass Media Ethics, 13:4, 219-231.

Valenti, J.M. (2000). Improving the scientist/journalist conversation. Science and Engineering Ethics, 6, 543-48.

Valenti, J.M. and L. Wilkins. 1995. An ethical risk communication protocol for science and mass communication. Public Understanding of Science, 4, 177-194.

Ward, B. (2004, November). Just thinking. Environment Writer. Retrieved December 20, 2004, from http://www.environmentwriter.org/ resources/think/1104_think.htm.

Weaver, D.H. and Wilhoit, G.C. (1994). Daily newspaper journalists in the 1990s. Newspaper Research Journal, 15, 2-21.

Weaver, D.H. and Wilhoit, G.C. (1996). The American Journalist in the 1990s: U.S. News People at the End of an Era. Mahwah, NJ: Lawrence Erlbaum. 
Weaver, D.H. and Wilhoit, G.C. (in press). The American journalist in the $21^{\text {st }}$ century. Retrieved December 20, 2004, from www.knightfdn. org/ publications/americanjournalist/aj_keyfindings.pdf. 